time,poor awareness among the former was much less $-13.8 \pm 1.5 \%$ than among the latter $32.2 \pm 1.5 \%(\mathrm{t}=8.68 ; \mathrm{P}<0.001)$ and even more so among the third $-50.1 \pm 2.7 \%(\mathrm{t}=5.79 ; \mathrm{P}<0.001)$.

$$
* * *
$$

1. Щербатых Ю.В. Психология стресса и методы коррекции. СПб : Питер 2008.

2. Codena J., Vinaccia S., Perez A. et al. The impact of disease activity on the quality of life, mental health status and family dysfunction in Colombian patients with rheumatoid arthritis.// J Clin Rheumatol 2008. 9: 3: 142-150.

3. Collins R.E., Lopez L.M., Marteau N.V. Emotional impact of screening: A systematic review and metaanalysis. // BMC Public Health 2011; 11: 603.

4. Новикова И.А., Сидоров П.И., Соловьев А.Г. Основные факторы риска развития психосоматических заболеваний. //Терапевтический архив, №1, 2007, ст.61-64.

5. $\quad$ Metcalfe C., Dovey Smith G., Sterne J.A., Heslop P., Macleod J., Hart C.L.(K) Cause-specific hospital admission and mortality among working men: Association with socioeconomic circumstances in childhood and adult life and the mediating role of daily stress.// Eur J Public Health 2009; 15:3: 238-244.

6. Reeder L., Champan J., Coulson A. Socioenvironmental stress, tranquilizers and cardiovascular disease//Proceedings of the Excerpta Medica International Congress Series. - 1968, 182, p.226-238.

\title{
Gasanova V.L. \\ Clinicoepidemiological analysis and immunological characteristics of allergic dermatitis with concomitant intestinal parasites
}

\author{
Azerbaijan Medical University \\ (Azerbaijan, Baku)
}

doi: 10.18411/scienceconf-09-2019-22

idsp: scienceconf-09-2019-22

\section{Аннотация}

Обследованы 510 больных с аллергодерматозами с сопутствующими паразитозами. Из них 139 больных с аскаридозам, 120 больных с энтеробиозом, 47 больных с стронгилоидозом, 77 с трихоцефалезом, 127 больных с лямблиозом. Проводились статистические, клинические, паразитологические и эпидемиологические методы исследование. Распределение больных аллергодерматозами с сопутствующими кишечными паразитозами по возрастным группам показало, что меньше всех больные были в возрасте $1-3$ года $(3,92 \pm 0,86 \%)$ и 51 и выше лет $(6,28 \pm 1,07 \%)$, несколько больных и почти одинаково больных были в возрасте $12-17$ лет $(13,33 \pm 1,51 \%)$, в возрасте $18-30$ лет $(14,51 \pm 1,56 \%)$ и в возрасте $31-50$ лет $(13,14 \pm 1,50 \%)$. Больше всех больные составляли в возрасте 8 -11 лет $(25,10 \pm 1,92 \%)$ и в возрасте $4-7$ лет $(23,73 \pm 1,88 \%)$

Распределение больных аллергодерматозов с сопутствующими аскаридозом, энтеробиозом, трихоцефалезом, лямблиозом было также как у больных с общими паразитозами, кроме стронгилоидоза. Аллергодерматозы с сопутствующими кишечными паразитозами среди населения Азербайджана и в настоящее время встречаются очень часто. Эти больные встречаются во всех возрастных группах. Частота встречаемости аллергодерматозов с сопутствующими паразитозами среди женщин и мужчин, а также по месту жительства отмечается по нозологии кишечных паразитов.

Ключевые слова: дети, взрослые, аллергодерматозы, паразитозы

Among the many etiological factors parasitological diseases occupy a special place.[1] Pathogens of some parasitic diseases penetrate the skin into the body, some live in the skin and subcutaneous tissue, and intestinal parasites with their metabolic substance affect the morphological and functional activity of the skin.[2]

Allergodermatoses are one of the most common skin pathologies among the populations of many countries of the world [3], including Azerbaijan. 
However, a special study to study the role of parasitic diseases, especially intestinal parasites in the emergence of pathogenesis and clinical course of allergodermatosis in the country has not been conducted.

Purpose. To study the epidemiological features of allergodermatoses with concomitant intestinal parasitoses.

Method of research. Surveyed 510 patients with allergic dermatitis with concomitant parasitosis. Of these, 139 patients with ascariasis, 120 patients with enterobiosis, 47 patients with strongyloidosis, 77 with trichocephalosis, 127 patients with giardiasis.

Statistical, clinical, parasitological and epidemiological methods of research were carried out.

Survey results and discussion. Distribution of patients with allergodermatoses with concomitant intestinal parasitosis by age groups showed that the least of all patients were aged 13 years $(3.92 \pm 0.86 \%)$ and 51 years and above $(6.28 \pm 1.07 \%)$, several patients and almost equally patients were aged $12-17$ years $(13.33 \pm 1.51 \%)$, aged $18-30$ years $(14.51 \pm 1.56 \%)$ and aged $31-50$ years $(13.14 \pm 1.50 \%)$. Most patients were aged $8-11$ years $(25.10 \pm 1.92 \%)$ and aged $4-7$ years $(23.73 \pm 1.88 \%)$

The distribution of allergic patients with concomitant ascariasis, enterobiasis, trichocephalosis, giardiasis was also as in patients with a common parasitosis, except Strongyloides.

With the allergic strongyloidiasis among children aged 1-3 is not met, patients most of all is found in the age of 18-30 years (loss of $25.53 \pm 6,36 \%)$ and aged $31-50$ years $(21,28 \pm 5,97 \%$ ), then at the age of 8-11 years (of $17.02 \pm 5,48 \%$ ) and age $12-17$ years $(14,89 \pm 5,19 \%)$, and less than all the same aged $4-7$ years and 51 and above $(10,64 \pm 4,50 \%)$.

The distribution of patients by place of residence was analyzed. The number of patients with allergic dermatoses with ascariasis living in rural areas $(63,31 \pm 4,09 \%$; $\mathrm{P} 0,001)$ was significantly higher than the number of patients living in urban areas $(36,69 \pm 4,0 \%)$. The same picture is seen in patients with allergic dermatitis with concomitant strongyloidiasis and trihozefaleza.

The number of patients with concomitant allergic enterobiasis living in cities (of $54.17 \pm 4,55 \%)$ than patients living in rural areas $(45,83 \pm 4,55 \%$; $\mathrm{P} 0,05)$ and the number of allergic patients with giardiasis living in cities $(50,39 \pm 4,44 \%)$ and villages $(49,61 \pm 4,44 \%$; $\mathrm{P} 0,05)$ is almost the same.

Moreover, there was analyzed the occurrence of allergic, with the accompanying separate nosological forms of intestinal parasitosis. Among patients with allergodermatoses with concomitant ascariasis, the number of women is greater $(51.80 \pm 4.24 \%)$ than men $(48.20 \pm 4.24 \%$; $\mathrm{P} 0,05)$.

The same pattern is reported among patients with allergic enterobiasis with trihozefaleza and giardiasis (respectively $59,17 \pm 4,49 \%$ and $40,83 \pm 4,49 \%, \mathrm{P} 0,05 ; 53,25 \pm 5,69,69 \%$ and $46,75 \pm 5,69 \%$; P0, $05 ; 53,54 \pm 4,43 \%$ and of $46.46 \pm 4,43 \%$, P0,05). However, among patients with allergic dermatoses with concomitant strongyloidosis, the number of women $(42.55 \pm 7.21 \%)$ is less than the number of men $(57.45 \pm 7.21 \%, \mathrm{P} 0,05)$.

Conclusion. Allergodermatoses with concomitant intestinal parasites are still very common among the population of Azerbaijan. These patients occur in all age groups. The incidence of allergodermatosis with concomitant parasitosis among women and men, as well as in the community is marked by nosology of intestinal parasites.

1. Kajdanek T.V., Muhametzjanov A.M., Asylgareeva G.M., dr. Analiz zabolevaemosti naibolee rasprostranennymi parazitozami v Respublike Bashkortostan. Medicinskij vestnik Bashkortostana. - 2015. T. 10. - № 1. - s. 10-14.

2. Tumol'skaja N.I., Golovanova N.Ju.,. Zavojkin V.D Klinicheskie maski parazitarnyh boleznej. Infekcionnye bolezni: novosti, mnenija, obuchenie. - 2014. - № 1. - S. 17-27.

3. Tumol'skaja N.I. Allergicheskie reakcii pri parazitozah u detej. Russkij medicinskij zhurnal. - 2014. -T. 22. № 14. - 1072-1075. 